\title{
Az antidiabetikumok kardiovaszkuláris szerepe a véletlen besorolásos vizsgálatokban és az újabb ajánlások világában
}

\author{
Bajnok László
}

Pécsi Tudományegyetem, I. sz. Belgyógyászati Klinika, Endokrinológiai és Anyagcsere Tanszék, Pécs

Levelezési cím: Prof. dr. Bajnok László, 7624 Pécs, Ifjúság út 13. E-mail: bajnok.laszlo@pte.hu

\begin{abstract}
A tiazolidindion csoportba tartozó pioglitazon pozitív szekunder kardiovaszuláris prevenciós hatásának körvonalazódása (PROactive Study) után tíz évig kiábrándítóak lettek azon tanulmányok, amelyek a szigorú (ACCORD, ADVANCE, VADT) vagy korai (NAVIGATOR, ORIGIN) glikémiás kontroll, továbbá az inkretin tengelyen ható szerek (SAVOR-TIMI 53, EXAMINE, TECOS, ELIXA), illetve egyéb tiazolidindion (RECORD) hatását vizsgálták. Igazi áttörést jelentett azonban az SGLT2-gátló csoport egyik tagjával, az empagliflozinnal végzett EMPA-REG OUTCOME, amelyben a kardiovaszkuláris halálozás, a szívelégtelenség miatti hospitalizáció és a kemény nephropathiás végpontok robusztus (35-44\%-os) mértékben mérséklődtek. Ezt követően kardiovaszkulárisan szignifikánsan előnyösnek bizonyult két GLP-1R-agonista szer, a liraglutid és semaglutid (LEADER és SUSTAIN-6), egyértelműen a pioglitazon (IRIS) és az SGLT2-gátló csoport egy másik tagja, a canagliflozin (CANVAS) is. Amiben a különböző, 2-es típusú diabéteszre vonatkozó ajánlások egységesek, az a metformin elsővonalbeli szerként történő alkalmazása (korszerű evidencia hiánya ellenére is) és az SGLT2-gátlók preferálása már a korai szakban.
\end{abstract}

Kulcsszavak: 2-es típusú diabétesz, SGLT2-gátlók, kardiovaszkuláris prevenció, ajánlások

Cardiovascular role of novel antidiabetics in randomized controlled trials and newer recommendations For 10 years after the promising secondary prophylactic effect of a thiazolidinedione, pioglitazone, studies testing (i) strict glycemic control (ACCORD, ADVANCE, VADT), (ii) early glycemic control (NAVIGATOR, ORIGIN), (iii) agents acting on the incretin axis ( SAVOR-TIMI 53, EXAMINE, TECOS, ELIXA) or (iv) another thiazolidinedione, rosiglitazone (RECORD) became frustrating. However, EMPA-REG OUTCOME with empagliflozin, a member of the SGLT2 inhibitor group, has been a real breakthrough in respect of marked reduction (35-44\%) of cardiovascular mortality, hospitalization for cardiac failure and hard nephropathic endpoints. Subsequently, the following antidiabetic drugs have been shown to have significant cardiovascular benefit: (i) two GLP-1R agonists, the liraglutide and semaglutide (LEADER and SUSTAIN-6), as well as (ii) pioglitazone (IRIS), this time clearly, and (iii) another SGLT2 inhibitor, canagliflozin (CANVAS). Where the different guidelines for type 2 diabetes are consistent are the usage of metformin as the first line drug (despite the lack of modern evidence) and the preference of SGLT2 inhibitors, even in the early stages.

Keywords: Type 2 diabetes, SGLT2 inhibitors, cardiovascular prevention, recommendations 


\section{Bevezetés}

Az amerikai és európai diabétesz társaságok (ADA/ EASD) 2015-ös közös ajánlása a metformin után a lehetséges hatástani csoportok - szulfanilurea, tiazolidindion, dipeptidil-peptidáz-4-gátló (DPP-4-gátló), nátrium-glükóz-kotranszporter-2 gátló (SGLT2-gátló), glükagonszerü peptid-1-receptor-agonista (GLP1R- agonista), bázisinzulin - közötti választás során a gyógyszerek hatékonysága mellett a hypoglykaemia-kockázatot, a testsúlyra gyakorolt hatást, a legfontosabb mellékhatásokat és a költségeket javasolja mérlegelni 2-es típusú diabéteszben (1). Hármas kombinációnak is lehet szerepe. Ezt követően bázis- és prandiális inzulin hozzáadása, valamint alternatívaként GLP-1R-agonista és bázisinzulin-kombináció szerepel. A diabéteszes koronáriabetegeken végzett BARI 2Dvizsgálatban az inzulinérzékenységet fokozó szerek preferálása (metformin alkalmazására 74,6\%-ban került sor, szemben az inzulin és/vagy szulfanilurea ág 10,5\%-ával) nem eredményezett érdemi különbséget a kardiovaszuláris kimenetelben (a súlyos hypoglykaemia 36\%-kal volt ritkább) (2). További - többek között - kardiovaszkuláris vizsgálatok vannak folyamatban az ígéretes metforminnal (3). Csalódást keltőek lettek a 2-es típusú diabéteszben végzett glikémiás típusú vizsgálatok is. Ezek metaanalízise, amely a UKPDS mellett négy korszerü, aktív vs. kontrollvizsgálatot elemzett (PROactive Study, ACCORD, ADVANCE, VADT) és amelyben az ágak közötti $\mathrm{HbA}_{1 c}-k u ̈-$ lönbség $6,4-7,0 \%$ vs. 7,3-8,4\% volt (4), a szigorú - $\mathrm{HbA}_{1 \mathrm{c}}$ $<7 \%$ - vércukor-kontroll makrovaszkuláris előnyét a koleszterin- és vérnyomáskezelés hatásánál gyengébbnek jelezte (5). Emiatt is irányul fokozott figyelem az antidiabetikumok glikémiás hatásán túli, pleiotrop szerepe felé. Az inkretin tengelyen ható szerek - GLP-1R-agonisták és DPP-4-gátlók - esetében például számos potenciális kardiovaszkuláris pozitív hatás mutatható ki (6).

Az utóbbi évek nagy, véletlen besorolásos vizsgálatai közül - bár indíttatásuk alapvetően biztonságossági, non-inferioritási volt - számos alkalmas a vércukor-csökkentésen túli kérdések vizsgálatára. Ezekben - a nyílt glikémiás betegadatok ismeretében - rendre bátorítást kaptak (kapnak) a vizsgálók a vércukorértékek besorolástól független javítására, hagyományos(abb) szerek igénybe vételével. Ezen vizsgálatok eredményeit és az újabb irányelvekre gyakorolt hatásait tekintjük át, kardiovaszkuláris szempontból.

\section{Az antidiabetikumok kardiovaszkuláris szerepe a véletlen besorolásos, nem glikémiás vizsgálatokban}

\section{Az SGLT2-gátlók kardiovaszkuláris végpontos vizsgálatai}

Több szempontból is mérföldkő-vizsgálat volt az SGLT2-gátló csoport egyik tagjával, az empagliflozin- nal végzett EMPA-REG OUTCOME (7), amely 7020 kardiovaszkuláris és egyidejüleg 2-es típusú cukorbeteg bevonásával, átlagosan 3,1 éves követési idővel történt. Korábban egyetlen megatrial sem tudta tisztán igazolni valamely antidiabetikum placebóval szembeni kardiovaszkuláris előnyét az elsődleges klinikai végpontok szintjén (a pioglitazon jutott legközelebb ehhez a PROactive Study-ban [8]; a UKPDS ui. nem modern elrendezésű és kezelési hátterü volt [9] és a mai standardok szerint már nem elegendő, mint evidencia [3]). A pesszimizmus odáig fokozódott, hogy az EMPA-REG OUTCOME megjelenése előtt nem sokkal egyes véleményformálók már felesleges erőforrás-pocsékolásnak nyilvánították az antidiabetikummal, az FDA előírásának megfelelően végzett non-inferioritási vizsgálatokat (10). Az EMPA-REG OUTCOME más szempontból is egy igazi meglepetés-vizsgálat volt: az összevont kardiovaszkuláris végpont (kardiovaszkuláris halálozás, nem halálos miokardiális infarktus és nem halálos stroke) az empagliflozinnal kezelt csoportban ugyan csak 14\%kal (szignifikánsan) csökkent a placebóhoz képest, de a különbség döntően a kardiovaszkuláris halálozás robusztus (38\%-os) csökkenéséből adódott. Ez az összmortalitásban is megmutatkozott (7); e mellett a szívelégtelenség miatti hospitalizáció is lényegesen ritkább volt. Az összevont mikrovaszkuláris szövődmények is szignifikánsan javultak az empagliflozinnal kezelt csoportban. A különbség a nephopathia progressziójában észlelt kedvező változásból adódott; a keményvégpontok (kreatinin kettőződés, vesepótló kezelés) kockázatának a csökkenése meghaladta a 40\%-ot (miközben az albuminuria megjelenését nem befolyásolta) (11). (A mikrovaszkuláris - és ezen belül a nephropathiás végpontokat - izoláltan [is] érdemes vizsgálni, mert összemosásuk eltakarhat fontos jelenségeket.)

Az egész nagyon emlékeztet a szigorú vérnyomáscsökkentés SPRINT-ben észlelt hatására (összmortalitásban is megmutatkozó, robusztus kardiovaszkuláris mortalitás-csökkenés és a szívelégtelenség miatti hospitalizáció jelentős javulása - legalábbis nem kardiovaszkuláris betegeken, miközben az iszkémiás kockázat nem csökken) (12), azzal a különbséggel, hogy az empagliflozin a nephropathiát javítja, az alacsonyabb vérnyomás pedig rontja.

A nephronok proximális tubulusaiban elhelyezkedő, a glükóz reabszorpció 90\%-áért felelős SGLT2 gátlása többszörös kedvező hatást gyakorol a metabolizmusra (HbA1c, testsúly, húgysav-csökkentés, HDL-C-emelés) és a hemodinamikai tényezőkre (olyan diuretikus hatás, aminek során nemcsak a vérnyomás, hanem az érfali merevség is csökken) $(13,14)$. Ezek azonban nem magyarázzák meggyőzően, hogy az iszkémiás események, a szívinfarktus, illetve stroke miért nem csökkentek érdemben az EMPA-REG OUTCOME során és ugyanakkor a kedvező hatás miért jelentkezett már a terápia első néhány hónapjában. Elképzelhető, hogy a háttérben az empagliflozin direkt myocardium hatá- 
sa áll. Adatok vannak ugyanis arra, hogy a myocardium hyperglykaemia miatt megnövekedett nátrium- és kalciumtartalmát az empagliflozin az SGLT2-gátlástól független mechanizmussal, a Na $/ \mathrm{H}^{+}$exchanger (NHE) blokkolása révén mérsékelni képes (15).

Az ez idáig befejezett másik, SGLT2-gátlóval, a Magyarországon nem forgalmazott canagliflozinnal végzett nagy vizsgálatba, a CANVAS-ba (Canagliflozin and Cardiovascular and Renal Events in Type 2 Diabetes) 10142 magas rizikójú T2DM-beteget vontak be, akiket átlagosan 3,6 évig követtek (16). A vizsgálat elsődleges végpontja (kardiovaszkuláris halálozás, nem halálos szívinfarktus, nem halálos stroke együttese) 14\%kal, statisztikailag szignifikánsan csökkent canagliflozin mellett. A kombinált nefrológiai végpont javulása nem bizonyult szignifikánsnak, de az albuminürítés, az eGFR-hanyatlás, a múvesekezelés és a vese eredetű halálozás tekintetében a készítmény lehetséges előnye mutatkozott, ugyanakkor meglepő módon az alsó végtagi amputációk számát növelte. Ezek 71\%-a lábujj és lábközépcsont magasságában történt (6,3 versus $3,4 / 1000$ betegév) (16). Hasonló megfigyelés nem volt empagliflozin, vagy dapagliflozin mellett (17).

\section{GLP-1R-agonistákkal végzett kardiovaszkuláris végpontos vizsgálatok}

Két GLP-1R-agonista szerrel született (eddig?) pozitív kardiovaszkuláris eredményü vizsgálat: liraglutiddal a LEADER (18) és semaglutiddal a sokkal kisebb statisztikai erejü, de lényegesen nagyobb placebóval szembeni $\mathrm{HbA}_{1 \mathrm{c}}$-csökkenést produkáló SUSTAIN-6 (19). A LEADER esetén különösen imponáló volt az összmortalitás csökkenése. Az elvártnak megfelelő lett az is, hogy a vizsgálatokban az iszkémiás események is szignifikánsan mérséklődtek (a LEADER-ben a szívinfarktus, a SUSTAIN-6 esetében a nem fatális stroke és revaszkularizáció). Kellemetlen meglepetést keltett azonban, hogy a SUSTAIN-6-ban a retinopathiás szövődmények gyakoribbá váltak. Ennek hátterében a gyors vércukorcsökkenés állhatott (19) (miközben az albuminuria javult az aktív ágakon).

A szintén GLP-1R-agonistával végzett ELIXA-ban a lixisenatidnak annak ellenére sem volt semmiféle pozitív makrovaszkuláris hatása, hogy szuperioritási vizsgálatként folyt (20). A 14000 beteg bevonásával és exenatiddal végzett, legújabb EXSCEL eredménye is semleges (bár a 65 feletti alcsoportban - hipotézist keltő módon - szignifikánsan előnyös) lett (21). Nem feltétlenül a GLP-1R-agonista szerek közötti különbségek magyarázzák a fenti diszkrepanciát, hanem a vizsgálatok sajátságai is állhatnak a háttérben, például a megengedett nyílt antidiabetikumok fajtái, ami például az EXSCEL-ben az ágak között aránytalan egyéb GLP-1R-agonista vagy SGLT2-gátló használatot eredményezett. Vagy, a liraglutiddal és a semaglutiddal végzett vizsgálatokban az induló $\mathrm{HbA}_{1 c}$ magasan a céltartomány feletti, 8,7\% volt (ahol a pleiotrop hatások fokozottan érvényesülhetnek), míg az ELIXA-ban „csak” 7,6\%, EXSCEL-ben 8,1\%. Vagy, az EXSCEL-ben nagyobb volt a lemorzsolódás.

\section{A DPP-4-gátlókkal végzett kardiovaszkuláris végpontos vizsgálatok}

A DPP-4-gátlók kardiovaszkuláris előnye nem igazolódott, sőt, saxagliptin mellett gyakoribb lett a szívelégtelenség (22). Ez, tendenciaszerüen az alogliptin esetében is kimutatható volt (23), bár a sitagliptin esetében nem (24). Az iszkémiás eseményekre gyakorolt hatás szempontjából megjegyzendő, hogy bár ezen vizsgálatokban az eseményszámok (a sitagliptinnel végzett TECOS esetében pl. n=1390) megfelelő statisztikai erőt biztosítottak volna a szuperioritás igazolásához is, a követési idő viszonylag rövid volt (a leghosszabb, a TECOS esetében is csak három év volt; ugyan hasonló időtartartam - 2,1-3,8 év - elegendő volt a fentebb említett sikeres GLP-1R-agonista vizsgálatoknak). A hypoglykaemiás epizódok sem lettek ritkábbak DPP-4gátlók esetében, mint a kontroll, hagyományos(abb) kezelési ágon (lehet, hogy ha a szigorú - $\mathrm{HbA}_{1 \mathrm{c}}<7 \%$ tartományba történt volna a vércukorcsökkentés, kiviláglott volna a gliptinek hypoglykaemia terén nyújtott előnye). (A GFR-romlás mértéke sitagliptin mellett szignifikánsan nagyobb volt.)

\section{A pioglitazonnal végzett kardiovaszkuláris végpontos vizsgálatok}

Már a korábbi PROACTIVE-alcsoport elemzése azt jelezte, hogy a pioglitazon képes mérsékelni a szívinfarktus és stroke ismétlődésének a kockázatát (25). Ez a megfigyelés azonban - mivel alcsoportokon és másodlagos végpontok tekintetében született - csak hipotézist keltő lehetett. Egy friss vizsgálat, az IRIS ezt a hipotézist igazolta, legalábbis cerebrovaszkuláris betegek esetében. A szer a placebóhoz képest előnyösen tudta befolyásolni a friss TIA-t vagy stroke-ot szenvedett, nem diabéteszes, de inzulinrezisztens betegek iszkémiás eseményeinek bekövetkeztét (OR: 0,76; $95 \% \mathrm{Cl}$ : 0,62-0,93) - nemcsak a stroke-ot, hanem a szívinfarktust is $(26,27)$, az új diabétesz incidenciájával együtt. Összehasonlításként: a glargin inzulin alkalmazásával folytatott ORIGIN 2000 feletti elsődleges végpontesemény mellett sem bizonyította a korán elkezdett aktív glikémiás vezetés pozitív hatását, sem makrovaszkuláris, sem mikrovaszkuláris szempontból (igaz a tumorincidencia sem nőtt) (28). Hasonlóképpen semleges lett a rövid hatású inzulin szekretagóg nateglinid alkalmazásával nagy kockázatú, csökkent glükóztoleranciájú betegeken végzett NAVIGATOR (nemcsak a vaszkuláris 
esemény, hanem az új diabétesz sem lett ritkább) (29). Tehát a pioglitazon jelenleg az egyetlen antidiabetikum, ami az iszkémiás eseményeket pleiotrop (nem glikémiás) módon, korszerü kezelési környezetben (pl. 8\%-nál nem magasabb $\mathrm{HbA}_{1 \mathrm{c}}$-ről indulva), meggyőzően csökkenteni tudja. Ezért méltatlan talán a pioglitazon kiszorulása a kardio- és cerebrovaszkuláris diabéteszes betegek hazai kezeléséből, akkor is, ha olyan jelentős mellékhatásai lehetnek a szernek, mint a szívelégtelenség vagy az osteoporosis gyakoriságának fokozódása (a súlygyarapodás nem annyira mellékhatás, mint inkább a hatás része - ezzel ugyanis összefügg a pozitív kardiovaszkuláris kimenetel [30]).

\section{Az antidiabetikumok kardiovaszkuláris szerepe az újabb állásfoglalásokban és ajánlásokban}

2016 decemberében az FDA elfogadta az empagliflozin javallataként a diabéteszes kardiovaszkuláris betegek mortalitásának csökkentését (31), ugyanakkor 2017 áprilisában nem ismerte el, hogy a sitagliptin kardiálisan biztonságosabb lenne, mint a többi DPP-4-gátló (32).

Az Európai Kardiológus Társaság 2016-os prevenciós irányelve elsővonalbeli szerként metformint javasol és - az EMPA-REG OUTCOME alapján - egyidejü kardiovaszkuláris betegség esetén, megfontolásra SGLT2-gátlót, már a diabétesz korai szakában (5).

A Klinikai Endokrinológusok Amerikai Társasága és az Endokrinológia Amerikai Kollégiuma (American Association of Clinical Endocrinologist and American College of Endocrinology; AACE/ACE) 2016-os közös kezelési algoritmusa az antidiabetikus kezelés személyre szabásánál alapvetően olyan szempontokat jelöl ki, mint a hatásosság, hatásmechanizmus, hypoglikaemia hajlam, a testsúlyra gyakorolt hatás, egyéb mellékhatások, tolerálhatóság, könnyü alkalmazhatóság, ár, biztonságosság (33). A gyógyszercsoportok ajánlott (kevés mellékhatás, lehetséges további előnyök) vagy fokozott óvatossággal használható jelzést kaptak. Az előbbibe, a Magyarországon használatosak közül a metformin, GLP-1R-agonisták, SGLT2-gátlók, DPP-4-gátlók és az alfa-glükozidáz-gátlók kerültek, az utóbbiba a tiazolidindionok, szulfanilureák, glinidek és a bázis inzulin. Egy adott hatástani csoport nettó előnyének mértékét skála jelzi. A metformin után ajánlott első helyen a GLP-1R-agonisták, majd az SGLT2-gátlók állnak, megelőzve a DPP-4-gátlókat, feltehetően az első két hatástani csoport glikémiás hatékonysága és egyéb járulékos előnyök (hasi zsírszövet és a testsúly csökkentése, lipidprofil javítása, hemodinamikai és egyéb kardiovaszkuláris rizikófaktorokra kifejtett hatás stb.) miatt. A 2016-os kanadai ajánlásban - a hatékonyság, hypoglykaemizáló és testsúlyra gyakorolt hatás mellett - külön szempont a kardiovaszkuláris végpontú vizsgálatok eredménye. Ezek alapján, ha a kardiovaszkuláris beteg glikémiás paraméterei javítást igényelnek, empagliflozin vagy liraglutid alkalmazását javasolják (34). Ezzel harmonizál az Amerikai Diabétesz Társaság (ADA) 2017-es állásfoglalása is (35).

Az American College of Physicians 2017-es irányelve csak az orális antidiabetikumokal foglalkozik. Ebben a metformin után SGLT2-gátló vagy DPP-4-gátló preferálása szerepel (36).

A Magyar Diabetes Társaság új és egyben az Emberi Erőforrások Minisztériuma felnőttkori antihyperglykaemiás kezelésre is vonatkozó, hatályos klinikai egészségügyi ajánlása a korábbi hazai irányelv továbbfejlesztése (37). Ez a nemzetközi állásfoglalásokhoz hasonlatos, amennyiben metformin az első választandó szer 2-es típusú diabéteszben (intolerancia vagy ellenjavallat esetén DPP-4-gátló preferálása), kombinációs kezelés tagjaként pedig DPP-4-gátló, SGLT2-gátló, GLP-1R-agonista, bázisinzulin vagy pioglitazon javasolt, de szulfanilurea, glinid vagy alfaglükozidáz-inhibitor (akarbóz) is adható. Az antidiabetikus kezelés megválasztásának betegközpontúnak kell lennie, figyelembe véve az antidiabetikum(ok) sajátosságait is. Mindennek áttekintését táblázat segíti, amiben a kardiovaszkulárisan igazoltan előnyös szerek a következők: metformin, empagliflozin, liraglutid és pioglitazon.

\section{Ko̊vetkeztetések}

A vércukor csökkentésének a módja is jelentőséggel bír és - bizonyos küszöb alatt - fontosabb lehet, mint maga a glikémiás kontroll. Az antidiabetikumokkal végzett vizsgálatok is terheltek a csoporthatás vagy azon belüli különbségek dilemmájával. Így: pio- vs. rosiglitazon, empa- vs. canagliflozin, saxa- vs. sitagliptin, lira-, semaglutid vs. lixise- vagy exenatid? Nagyon örvendetes, hogy az utóbbi időben kardiovaszkuláris szempontból meglehetősen általános az antidiabetikumok biztonságossága és egyre több készítményről bizonyosodik be, hogy a régebbi kezelési formákhoz képest előnnyel is rendelkezik.

\section{Köszönetnyilvánítás}

A jelen tudományos közleményt a szerző a Pécsi Tudományegyetem alapításának 650. évfordulója emlékének szenteli.

\footnotetext{
Irodalom

1. Inzucchi SE, Bergenstal RM, Buse JB, et al. Management of hyperglycemia in type 2 diabetes, 2015: A patient-centered approach: Update to a position statement of the American Diabetes Association and the European Association for the Study of Diabetes. Diabetes Care 2015; 38: 140-149. doi:10.2337/dc12-0413

2. BARI 2D Study Group, Frye RL, August P, et al. A randomized trial of therapies for type 2 diabetes and coronary artery disease. N Engl J Med 2009; 360: 2503-15. doi: 10.1056/NEJMoa0805796

3. Lexis CP, van der Horst IC. Metformin for cardiovascular disease:
} 
promise still unproven. Lancet Diabetes Endocrinol 2014; 2: 94-5. doi: 10.1016/S2213-8587(13)70171-2

4. Ray KK, Seshasai SR, Wijesuriya S, et al. Effect of intensive control of glucose on cardiovascular outcomes and death in patients with diabetes mellitus: a meta-analysis of randomised controlled trials. Lancet 2009; 373: 1765-72. doi: 10.1016/S0140-6736(09)60697-8 5. Piepoli MF, Hoes AW, Agewall S, et al. 2016 European Guidelines on cardiovascular disease prevention in clinical practice: The Sixth Joint Task Force of the European Society of Cardiology and Other Societies on Cardiovascular Disease Prevention in Clinical Practice. Eur Heart J 2016; 37: 2315-81. doi: 10.1093/eurheartj/ehw106

6. Ussher JR, Drucker DJ. Cardiovascular actions of incretin-based therapies. Circ Res 2014; 114:1788-803. doi: 10.1161/CIRCRESA HA.114.301958

7. Zinman B, Wanner C, Lachin JM, et al. Empagliflozin, Cardiovascular Outcomes, and Mortality in Type 2 Diabetes. N Engl J Med 2015; 373: 2117-28. DOI: 10.1056/NEJMoa1504720

8. Dormandy JA, Charbonnel B, Eckland DJ, et al. Secondary prevention of macrovascular events in patients with type 2 diabetes in the PROactive Study (PROspective pioglitAzone Clinical Trial In macroVascular Events): a randomised controlled trial. Lancet 2005; 366: 1279-89. DOI: 10.1016/S0140-6736(05)67528-9

9. UK Prospective Diabetes Study (UKPDS) Group. Effect of intensive blood-glucose control with metformin on complications in overweight patients with type 2 diabetes (UKPDS 34). Lancet 1998; 352: 854-65.

10. CV-Outcomes Trials With Diabetes Drugs: ,A Waste of Resources'. Medscape Sep 03, 2015.

11. Wanner C, Inzucchi SE, Lachin JM, et al. Empagliflozin and Progression of Kidney Disease in Type 2 Diabetes. N Engl J Med 2016; 375: 323-34. DOI: 10.1056/NEJMoa1515920

12. SPRINT Research Group. A randomized trial of intensive versus standard blood pressure control. N Engl J Med 2015; 373: 2103_ 2116. DOI: 10.1056/NEJMc1602668

13. Heerspink HJ, Perkins BA, Fitchett DH, et al. Sodium Glucose Cotransporter 2 Inhibitors in the Treatment of Diabetes Mellitus: Cardiovascular and Kidney Effects, Potential Mechanisms, and Clinical Applications. Circulation 2016; 134: 752-72. DOI: 10.1161/CIRCU LATIONAHA.116.021887

14. Abdul-Ghani M, Del Prato S, Chilton R, DeFronzo RA. SGLT2 Inhibitors and Cardiovascular Risk: Lessons Learned From the EMPA-REG OUTCOME Study. Diabetes Care 2016; 39: 717-25. DOl: 10.2337/dc16-0041

15. Baartscheer A, Schumacher CA, Wüst RC, et al. Empagliflozin decreases myocardial cytoplasmic $\mathrm{Na}+$ through inhibition of the cardiac $\mathrm{Na}^{+} / \mathrm{H}^{+}$exchanger in rats and rabbits. Diabetologia 2017; 60: 568-573. doi:10.1007/s00125-016-4134-x

16. Neal B, Perkovic V, Mahaffey KW, et al. Canagliflozin and Cardiovascular and Renal Events in Type 2 Diabetes. N Engl J Med 377:644-657. DOI: 10.1056/NEJMoa1611925

17. Fadini GP, Avogaro A. SGTL2 inhibitors and amputations in the US FDA Adverse Event Reporting System. Lancet Diabetes Endocrinol. 2017; 5: 680-681. DOI: doi: 10.1016/S2213-8587(17)302577. Epub 2017 Jul 18.

18. Marso SP, Bain SC, Consoli A, et al. Semaglutide and Cardiovascular Outcomes in Patients with Type 2 Diabetes. N Engl J Med 2016; 375: 1834-1844. DOI: 10.1056/NEJMoa1607141

19. Marso SP, Daniels GH, Brown-Frandsen K, et al. Liraglutide and Cardiovascular Outcomes in Type 2 Diabetes. N Engl J Med 2016; 375: 311-22. DOI: 10.1056/NEJMoa1603827

20. Pfeffer MA, Claggett B, Diaz R, et al. Lixisenatide in Patients with
Type 2 Diabetes and Acute Coronary Syndrome. N Engl J Med 2015; 373: 2247-57. DOI: 10.1056/NEJMc1600140

21. Holman RR, Bethel MA, Mentz RJ, et al. Effects of Once-Weekly Exenatide on Cardiovascular Outcomes in Type 2 Diabetes. N Engl J Med. 2017; 377:1228-1239. DOI: 10.1056/NEJMoa1612917 Epub 2017 Sep 14

22. Scirica BM, Bhatt DL, Braunwald E, et al. Saxagliptin and cardiovascular outcomes in patients with type 2 diabetes mellitus. N Engl J Med 2013; 369: 1317-26. doi: 10.1056/NEJMoa1307684

23. White WB, Cannon CP, Heller SR, et al. Alogliptin after acute coronary syndrome in patients with type 2 diabetes. N Engl J Med 2013; 369: 1327-35. doi: 10.1056/NEJMoa1305889

24. Green JB, Bethel MA, Armstrong PW, et al. Effect of sitagliptin on cardiovascular outcomes in type 2 diabetes. N Engl J Med 2015; 373: 232-42. Doi: 10.1056/NEJMoa1501352

25. Betteridge DJ, DeFronzo RA, Chilton RJ. PROactive: time for a critical appraisal. Eur Heart J 2008; 29: 969-83. doi: 10.1093/eur. heartj/ehn114

26. Kernan WN, Viscoli CM, Furie KL, et al. Pioglitazone after Ischemic Stroke or Transient Ischemic Attack. N Engl J Med 2016; 374: 1321-31.DOI: 10.1056/NEJMoa1506930

27. Young LH, Viscoli CM, Curtis JP, et al. for the IRIS investigators. Cardiac outcomes after ischemic stroke or transient ischemic attack: effects of pioglitazone in patients with insulin resistance without diabetes mellitus. Circulation 2017; 135: 1882-1893. doi: 10.1161/CIR CULATIONAHA.116.024863

28. ORIGIN Trial Investigators, Gerstein HC, Bosch J, et al. Basal insulin and cardiovascular and other outcomes in dysglycemia. N Engl J Med 2012; 367: 319-28 DOI: 10.1056/NEJMoa1203858

29. NAVIGATOR Study Group, Holman RR, Haffner SM, et al Effect of nateglinide on the incidence of diabetes and cardiovascular events. N Engl J Med 2010; 362: 1463-76. DOI: 10.1056/NE. Moa1001122

30. Doehner W, Erdmann E, Cairns R, et al. Inverse relation of body weight and weight change with mortality and morbidity in patients with type 2 diabetes and cardiovascular co-morbidity: an analysis of the PROactive study population. Int J Cardiol 2012; 162: 20-6. DO 10.1016/j.ijcard.2011.09.039

31. FDA Approves Empagliflozin for Reducing CVD Death - Medscape - Dec 02, 2016.

32. FDA Rejects Merck's Bid to Add Heart Data on Diabetes Drug Labels - Medscape-Apr 07, 2017.

33. Consensus Statement by the American Association of Clinical Endocrinologist and American College of Endocrinology on the Comprehensive Type 2 Diabetes Management Algorithm - 2016, Executive Summary. Endocrin Pract 2016; 22: 84-102.

34. Booth G, Lipscombe L, Butalia S, et al. Pharmacologic Management of Type 2 Diabetes: 2016 Interim Update. Canadian Journal of Diabetes 2016; 40: 484-6. DOI: 10.1016/j.jcjd.2016.02.006

35. American Diabetes Association. 8. Pharmacologic Approaches to Glycemic Treatment. Diabetes Care 2017; 40(Suppl 1): S64-S74.

36. Qaseem A, Barry MJ, Humphrey LL, et al. Oral Pharmacologic Treatment of Type 2 Diabetes Mellitus: A Clinical Practice Guideline Update From the American College of Physicians. Ann Intern Med. 2017; 166: 279-290.

37. Gaál Zs, Gerő L, Hidvégi T, Jermendy Gy, et al. Egészségügyi szakmai irányelv - A diabetes mellitus kórismézéséről, a cukorbetegek antihyperglykaemiás kezeléséről és gondozásáról felnőttkorban. Jermendy Gy, szerk. Diabetologia Hungarica 2017; 25(1): $3-77$.

A közlemény megjelenését a Boehringer Ingelheim támogatta. Az itt közölt információk a szerző nézeteit tükrözik, ami eltérhet a Boehringer Ingelheim álláspontjától. A megemlített készítmények használatakor az érvényes alkalmazási előírás az irányadó. Kód: HU/EMP/1017/00124 Lezárás dátuma: 2017.10.31. 